\title{
Inverted ovariosalpingohisterectomy technique in cats: advantages and limitations
}

\section{Técnica de ovariossalpingohisterectomia invertida em gatas: vantagens e limitações}

\author{
Ana Carolina de Souza Campos ${ }^{*} \oplus$, Maria Eduarda dos Santos Lopes Fernandes ${ }^{\circledR} \odot$, \\ Virgínia Conceição Tavares Lima ${ }^{2} \odot$, Michelle Lussac Silva ${ }^{3} \odot$, William de Almeida Oliveira ${ }^{4}($, \\ Giovanna Finklstein Teixeira ${ }^{\circledR}$, Ana Elisa da Cruz Ferri ${ }^{\circledR}$, Marta Fernanda Albuquerque da Silva ${ }^{6}$
}

\begin{abstract}
The inverted ovariosalpingohysterectomy (OSH) technique involves initial uterine removal, followed by ovarian disinsertion. The objective of this study was to compare the inverted technique with the traditional technique, characterized by initial removal of the ovaries followed by uterine resection, for evaluating the performance of the inverted OSH technique in cats. For this, 24 healthy, female cats, aged between 7 months and 5 years, with a body condition score of up to 6 points (9-point scale), divided into two equal groups: the traditional technique (TT) and the inverted technique (IT). Procedures were performed by the same veterinarians (surgeon and their assistant) as well as semi-quantitative analysis of the techniques (questionnaire related to the ease of uterine and ovarian manipulation as well as of intestinal and urinary vesicle manipulation) and descriptive qualitative analysis (technical report with the opinion of surgeons and an external evaluator). In addition, the total surgical time and positive pain response were evaluated, indicated by the changes in vital parameters observed by the anesthesiologist during surgery. Inverted technique it promoted greater ovarian exposure, allowing uterine cranial flexion to perform the ligatures, thus facilitating their manipulation, hemostasis, and section of the pedicle. Free the uterus from its ligaments to the abdominal cavity allowed greater mobilization of the conjoint. Both techniques required short operation time (average time of $16^{\prime} \pm 1.321^{\prime}$ in the IT group and $15^{\prime} \pm 0.525^{\prime}$ in the TT group). The presence of algetic stimulus was similar in the techniques, three animals in each group suffered analgesic rescue.
\end{abstract}

KEYWORDS: Pain; Surgical technique; Ovarian exposure; Feline.

RESUMO: A técnica de ovariossalpingohisterectomia (OSH) invertida envolve a remoção inicial uterina seguida da desinserção ovariana bilateral. O objetivo deste estudo foi comparar a técnica invertida com a tradicional, caracterizada pela remoção inicial dos ovários seguida da ressecção uterina, a fim de avaliar aspectos de execução da OSH Invertida em gatas. Para isso, 24 felinas hígidas, com idade entre 7 meses e 5 anos, com escore de condição corporal até 6 pontos (escala 9 pontos), foram divididas em dois grupos iguais (TT- técnica tradicional e TI- técnica invertida). As cirurgias e anestesias foram efetuadas pelos mesmos médicos veterinários, as técnicas foram avaliadas pelo cirurgião e auxiliar por análises semiquantitativa (questionário com escores relativos à facilidade de manipulação uterina e ovariana, nível de manipulação do intestino e vesícula urinária) e qualitativa descritiva (relatório das técnicas com opiniáo dos cirurgióes e avaliador externo). Ainda, avaliou-se o tempo cirúrgico total e a indicação de resposta álgica positiva conforme mudanças nos parâmetros vitais no transoperatório. A OSH invertida nos felinos não revelou diferença estatística na análise semiquantitativa quando comparada à técnica tradicional. Porém, promoveu maior exposiçáo ovariana permitindo a flexão cranial uterina, facilitando sua manipulaçáo, hemostasia e secção do pedículo. Ainda, a liberação do útero dos ligamentos à cavidade abdominal permitiu maior mobilização do conjunto. Ambas as técnicas revelaram-se de rápida execução sendo a média de tempo no TI de $16^{\prime} \pm 1,321^{\prime}$, e no TT de $15^{\prime} \pm 0,525^{\prime}$. A presença de estímulo álgico foi semelhante nas técnicas havendo resgates analgésicos em três animais de cada grupo.

PALAVRAS-CHAVE: Dor; Técnica cirúrgica; Exposição ovariana; Felino.

¿Doutoranda e Mestre do Programa de Pós-graduação em Medicina Veterinária da Universidade Federal Rural do Rio de Janeiro, Seropédica/RJ, Brasil

¿Mestre em Medicina Veterinária pelo Programa de Pós-graduação em Medicina Veterinária da Universidade Federal Rural do Rio de Janeiro, Seropédica/RJ, Brasil

${ }^{3}$ Residente em Clínica-cirúrgica de Animais de Companhia pela Universidade Federal Rural do Rio de Janeiro, Seropédica/RJ, Brasil

${ }^{4}$ Residente em Anestesiologia Veterinária pela Universidade de Brasília, Brasília/DF, Brasil

Médica Veterinária pela Universidade Federal Rural do Rio de Janeiro, Seropédica/RJ, Brasil

'Professora titular do Departamento de Medicina e Cirurgia Veterinária da Universidade Federal Rural do Rio de Janeiro, Seropédica/RJ, Brasil

*Corresponding author: carolvetcampos@outlook.com

Received: 26/10/2020. Accepted: 08/02/2021 


\section{INTRODUCTION}

Ovariosalpingohysterectomy (OSH) is the surgical technique for excision of the uterus, ovaries, and fallopian tubes and corresponds to the most commonly performed abdominal surgery in veterinary medicine (MIGLIARI; DE VUONO, 2000; DEL CARLO; BORGES, 2018). The limitation of reproduction is its initial indication, for avoiding estrus and undesirable offspring (MACPHAIL, 2014). However, it can be performed in the treatment or prevention of diseases of the female reproductive system, as in cases pyometra; in the prevention of breast neoplasms and other conditions (MACPHAIL, 2014; DEL CARLO; BORGES, 2018). The development of veterinary surgery requires the search for less invasive and traumatic surgical techniques that, consequently, generates less pain and causes fewer postoperative complications to the animal (FERREIRA et al., 2011).

In the current context, this study aimed to analyze and extend the application of the inverted OSH technique previously described in bitches to the feline species (CAMPOS et al., 2020). Such surgery consists of the initial ligatures of the middle uterine arteries and transection of the uterine body followed by ligation of the ovarian arteriovenous complex and bilateral ovarian resection, the opposite of what is considered as the traditional technique in the literature by the authors (MACPHAIL, 2014; DEL CARLO; BORGES, 2018). The OSH technique, as a basis for the traditional pattern in the current study, used only hemostatic forceps distal to the ovary, previously positioned before the ligation of the ovarian arteriovenous complex (DÁVID; KASPER, 2000).

The objective of this study was to evaluate aspects of the execution of the inverted OSH operative technique in cats, such as access to the ovaries and ovarian pedicle, visceral mobilization and manipulation, and total surgical time, in addition to the production of algetic stimulus, in comparison with the traditional technique, and analyzing the possible advantages and limitations of inverted $\mathrm{OSH}$ in this species.

\section{MATERIAL AND METHODS}

\section{Selection of patients}

This study was carried out after approval by the Ethics Committee on the Use of Animals in Research of UFRRJ under number 1342140618. Twenty-four female felines, aged between 7 months and 5 years, with a body condition score of up to six points (on a nine-point scale), clinically healthy, and with anesthetic risk ASA I, were considered for this study. They were patients sent for elective castration in the Birth Control Program for Dogs and Cats at UFRRJ, and therefore, all had tutors who were informed about the research and who authorized to participate by signing the informed consent form. The study was submitted to and approved by the Ethics Committee on the Use of Animals (CEUA) in the Research under number 1342140618.

\section{Experimental Groups}

The animals were randomly divided (by draw) into two groups, equally, called the traditional technique (TT) and inverted technique (IT). The traditional OSH technique was defined by the initial removal of the ovaries preceded by the execution of ligatures in the arteriovenous complex, with the use of only hemostatic forceps positioned distal to the ovary (to avoid the return of blood after ovarian disinsertion), followed by uterine resection. The inverted technique, adapted from the previous one, began with ligatures on the uterine body and its transection, followed by ligation of the ovarian arteriovenous complex and bilateral ovarian disinsertion. Both techniques used median longitudinal celiotomy as the access method.

\section{Anesthesia and surgery}

Upon reaching the site of the experiment, each animal was allocated to an individual cage and kept in acclimatization for $30 \mathrm{~min}$. Subsequently, baseline physiological parameters (MB) were measured: heart rate $(\mathrm{HR})$, respiratory rate $(f)$, systolic blood pressure (SBP), and rectal temperature (T); presence of any pain was assessed. Next, preanesthetic medication consisting of $0.3 \mathrm{mg} / \mathrm{kg}$ of methadone plus $0.5 \mathrm{mg} / \mathrm{kg}$ of ketamine was administered intramuscularly (IM). After 15 minutes, in the preparation room, venous access was performed in the cephalic vein and anesthesia induction with propofol $(3-5 \mathrm{mg} / \mathrm{kg}$ of propofol intravenously - IV) was started until unconsciousness, signs of mandibular relaxation and absence of eyelid reflex were observed; $10 \%$ lidocaine was instilled at a dose of $0.1 \mathrm{~mL} / \mathrm{animal}$ in the arytenoids and epiglottis for orotracheal intubation. Then, with the patient in the operating room in the supine position, the surgical field was shaved and aseptically prepared in a routine manner. Benzyl benzylpenicillin (1200000 IU) was administered at a dose of $40000 \mathrm{IU} / \mathrm{kg}$ IM. The distance between the xiphoid process and the pubis was measured, and a line measuring $1 / 3$ of that distance was marked with a dermographic surgical pen in the ventral midline to delimit the incision site, starting $1 \mathrm{~cm}$ caudally to the umbilical scar, where lidocaine was infiltrated in the subcutaneous tissue at a dose of $3 \mathrm{mg} / \mathrm{kg}$. Anesthesia was maintained using isoflurane 1.2 to 1.5 of minimum alveolar concentration (CAM), and the solution of choice for fluid therapy was lactated ringer at a rate of $3 \mathrm{~mL} / \mathrm{kg} / \mathrm{h}$.

The physiological parameters were measured again (HR, $\mathrm{f}, \mathrm{SBP}$, and T) after induction. At the moment of stabilization of the CAM and the anesthetic plan, these values were considered as the reference for subsequent measurements; therefore, termed as, moment 0 (M0). The surgical technique was then started (Board 1). The anesthetist and his assistant were not aware of it, since a visual barrier was placed between the anesthetist's location and the animal's body, preventing the visual identification of the surgery and observation, by the surgeons, of the anesthetic parameters and complications during the entire procedure. Both the surgical procedure and 


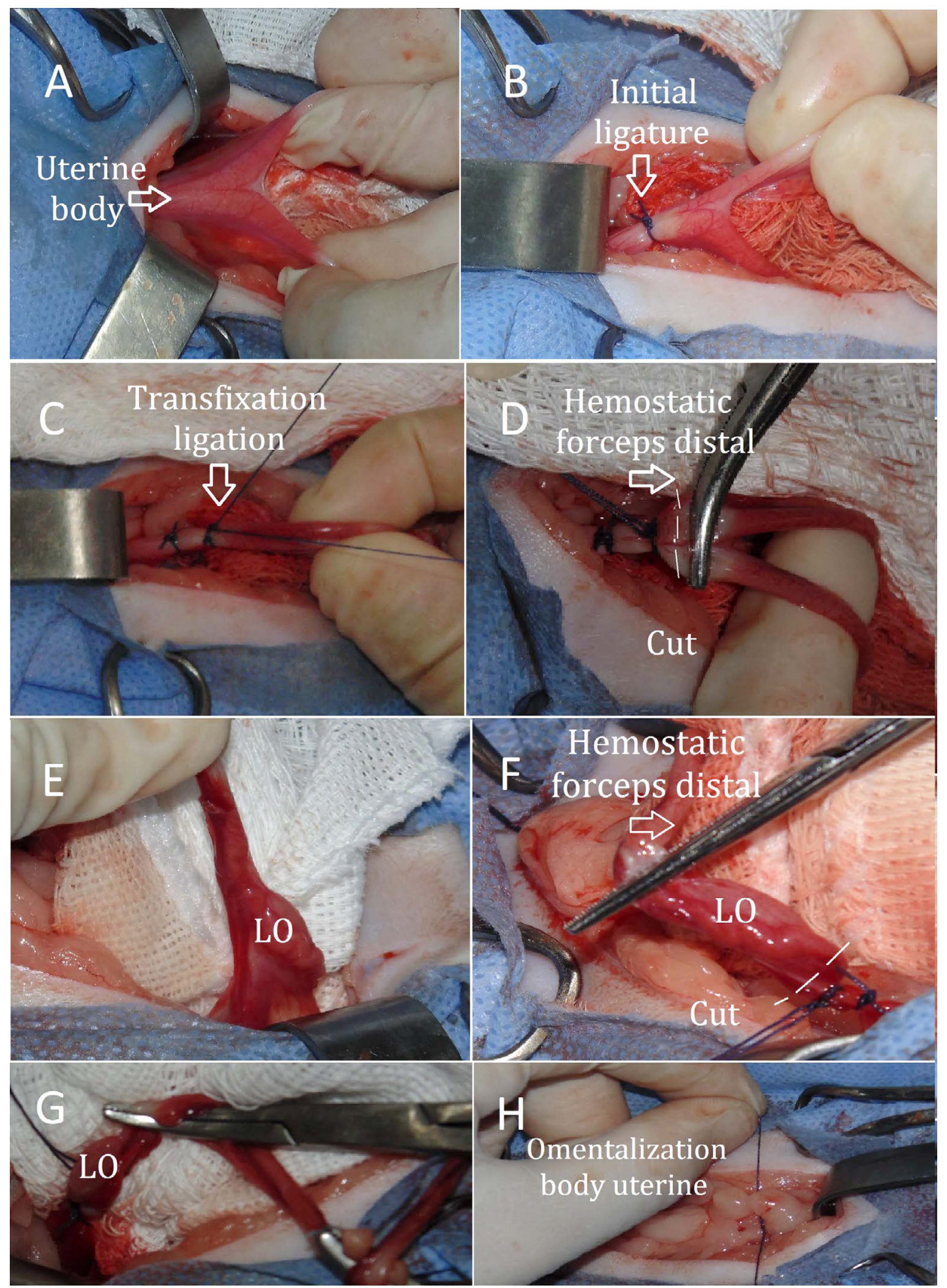

Board 1. Technique of inverted ovariosalpingohisterectomy in cat. A. Access by median longitudinal celiotomy, exposure of the uterine body. B. After making "windows" parallel to the middle uterine arteries in the broad ligament, total ligation of the uterine body is performed (highlighted). C. Distal to the initial ligation, ligation by transfixation is performed (highlighted). D. A hemostatic forceps is positioned distally to the ligation by transfixation, cutting (highlighted in the started line) distal to the transfixation. E. After laceration of the left broad ligament, the left ovary (LO) is located. F. Total ligation is performed in the left ovarian arteriovenous complex, distally ligation by transfixation is performed. A hemostatic forceps is positioned distal to the ovary (highlighted) to prevent reflux blood and cutting with a scalpel or scissors is performed distally to the transfixation (highlighted in the raised line). G. Elimination of the release of the whole set, the right ovary is located and the same procedure as the previous LO is performed. $H$. At the end, an omentalization is done in the uterine body that had a repaired thread. It proceeds with a routine synthesis of the abdominal, subcutaneous wall and skin. 
anesthesia were performed by the same specialized veterinary professional. The anesthetist monitored the physiological parameters and when there was an increase of more than $20 \%$ in two or more of the parameters (HR, $f$, and SBP), it was registered as a positive pain response, and analgesic rescue was instituted with $2 \mu \mathrm{g} / \mathrm{kg}$ of fentanyl, IV.

The raffia of the abdominal wall was made with "X" stitches and non-absorbable monofilament polyamide (nylon) thread number 2.0, followed by suturing the subcutaneous cellular tissue with polyglactin thread 910 number 3.0 in a mattress pattern. The skin was sutured with non-absorbable monofilament polyamide (nylon) thread number 3.0 in Sultan sutures (or in "X").

\section{Evaluation of surgical techniques}

After the end of the surgery, in a semiquantitative analysis, the veterinary surgeon and the surgical assistant answered a questionnaire adapted from Da Silva and collaborators (2013), in the format of closed questions, in which they could classify the ease of handling for hemostasis execution, uterine section, and disinsertion of the ovaries as poor (1), good (2), or excellent (3); the manipulation level of abdominal organs adjacent to the reproductive system (intestine and urinary vesicle) as little (1), medium (2), or intense (3).

As a descriptive evaluation, at the end of the study, surgeons and the external evaluator (the veterinary surgeon who attended all surgeries) were asked to write a short report with their opinion on the comparative analysis between traditional and inverted techniques. They were asked to take into consideration the anatomical characteristics of the species and to mention any item, even if subtle, that had conferred any advantage or disadvantage in each technique. In all evaluations, surgeons were asked not to discuss the findings with each other.

During the study, the same team member timed each surgery and recorded it in minutes and seconds; the counting started after the incision at the abdominal wall and stopped after the last skin suture was performed. The number of animals that required analgesic rescue in the trans-surgical area was also computed and classified as presence of a positive algetic stimulus.

\section{Statistical analysis}

The statistical analysis of the obtained results (time intervals between the experimental groups and assigned scores according to scores) was performed using the statistical program SigmaPlot version 11, and for detecting significant statistical differences, it was considered $\mathrm{p}<0.05(5 \%)$. Scores of the semiquantitative analysis were transformed into logarithms to allow comparison using the Mann-Whitney test. The Shapiro-Wilk normality test was used, followed by the Student's t-test, to compare the average of the independent samples; the Mann Whitney test was used for non-parametric data (surgical time).

\section{RESULTS AND DISCUSSION}

The search for OSH techniques that reduce trans-surgical and postoperative complications is relevant, because when performed electively it can reduce the uncontrolled reproduction responsible for the overpopulation of stray animals (CONCEIÇÃO et al., 2016).

No hemorrhage of the body wall was observed during the surgeries, or during visceral manipulation, and no serious surgical complications were experienced; only an additional hemostatic forceps was placed on a cat's body after manipulation and partial rupture of the serous and the uterine muscle. The surgeon's experience may have contributed to the low occurrence of complications because the rate of hemorrhages in OSH surgeries is mostly associated with the surgeon's inexperience (SANTOS et al., 2009). In addition, the patient who required additional hemostasis weighed only $2.1 \mathrm{~kg}$ and was young; therefore, the small size of her viscera and her immature body development may have facilitated uterine rupture under traction, since pediatric tissues are more fragile compared to adults and thus, handling it requires more caution (MACPHAIL, 2014; FIGUEIREDO, 2011).

In the semiquantitative analysis, the same score values were assigned to both ovaries; thus, all the cats in the IT group were classified with an excellent score and, in the traditional technique group, there was one good and one bad score (4.17\% each). In the evaluation of the same characteristic in the uterus, there were only excellent scores in IT group and, in the TT group, one good score and 11 excellent, as shown in Table 1. There was no statistical difference when comparing data from the right and left ovaries ( $\mathrm{p}=0.162)$, and the uterus $(\mathrm{p}=0.338)$, between the groups. This probably occurred due to the exclusion of cats with a body score greater than 6 points (on a 9 point scale) and the ease of performing $\mathrm{OSH}$ techniques in this species because the small size of the cats, the smaller size of the viscera, and body area allow better access to the ovarian pedicles, which facilitates their manipulation, hemostasis, and disinsertion.

As for the level of adjacent organ manipulation (urinary vesicle and intestine), a score was noted regarding little manipulation required in the organs with a percentage of $91.67 \%$ in the IT and $87.5 \%$ in the TT group. In addition, an average handling score was given for two IT animals (8.33\%) and three in the TT group (12.5\%). There was no statistical difference between the groups $(p=0.654)$, perhaps because obese cats were excluded from the study since the $\mathrm{OSH}$ technique is impaired in animals with a greater body weight as it requires higher manipulation of the organs during surgery, because there is a high amount of fat in the ligaments of these animals.

In the qualitative descriptive analysis of the surgeon, surgery assistant, and external evaluator, it was mentioned that the inverted technique promoted greater ovarian exposure because it allowed uterine cranial flexion to perform ligations of the ovarian arteriovenous complexes, thereby facilitating their manipulation, hemostasis, and pedicle section. However, it 
Table 1. Semiquantitative evaluation of the ease of manipulation to perform hemostasis and disinsertion of the right ovary, left ovary and uterine section of cats from the Birth Control Program of Dogs and Cats of the UFRRJ in the execution of OSH by means of two different surgical techniques, traditional (TT) and inverted (IT), from August 2018 to January 2019. The data are expressed as the number of animals classified by the surgeon and the surgeon's assistant in each score, percentage of classification and comparison between the groups by the non-parametric statistical test of Mann-Whitney.

\begin{tabular}{|c|c|c|c|c|c|c|c|c|c|c|}
\hline \multicolumn{5}{|c|}{ Right ovary } & \multicolumn{3}{|c|}{ Left ovary } & \multicolumn{3}{|c|}{ Uterus } \\
\hline \multicolumn{2}{|c|}{ Scores } & Exc & Good & Bad & Exc & Good & Bad & Exc & Good & Bad \\
\hline \multirow{3}{*}{ Groups } & IT & $\begin{array}{c}24 \\
100 \%\end{array}$ & 0 & 0 & $\begin{array}{c}24 \\
100 \%\end{array}$ & 0 & 0 & $\begin{array}{c}24 \\
100 \%\end{array}$ & 0 & 0 \\
\hline & TT & $\begin{array}{c}22 \\
91,6 \%\end{array}$ & $\begin{array}{c}1 \\
4,2 \%\end{array}$ & $\begin{array}{c}1 \\
4,2 \%\end{array}$ & $\begin{array}{c}22 \\
91,6 \%\end{array}$ & $\begin{array}{c}1 \\
4,2 \%\end{array}$ & $\begin{array}{c}1 \\
4.2 \%\end{array}$ & $\begin{array}{c}23 \\
95.8 \%\end{array}$ & $\begin{array}{c}1 \\
4.2 \%\end{array}$ & 0 \\
\hline & \multicolumn{4}{|c|}{$p=0.162$} & \multicolumn{3}{|c|}{$p=0.162$} & \multicolumn{3}{|c|}{$p=0.338$} \\
\hline
\end{tabular}

EXC- excellent.

was reported that the release of the uterus from its ligaments to the abdominal cavity performed in this technique allowed greater mobilization of the conjoint.

Both techniques proved to be fast to perform in the feline species, with an average time of $16^{\prime} \pm 1.321^{\prime}$ in the IT group, and of $15^{\prime} \pm 0.525^{\prime}$ in the TT group, with no statistical difference between the groups $(\mathrm{p}=0.529)$. The short surgical time is essential because the higher occurrence of complications is related to longer duration of anesthesia (MURARO; WHITE, 2014). A shorter surgical time was expected in the TT group, as the team often performed this technique, but the practical inexperience of veterinarians in the inverted technique did not generate longer execution time, even though it is a relevant factor, as the lack of experience can increase the OSH operative time (ATALLAH et al., 2013).

Regarding the presence of algetic stimulus, there were analgesic rescues in three animals in each group, revealing that there is no difference between the techniques in this species. This finding was opposite to that reported in the canine species, in which the traditional technique provided a greater need for rescues, essentially during the traction of the right ovary during surgery (CAMPOS et al., 2020).

The choice of the OSH technique to be performed significantly depends on the professionals' discretion. Thus, the surgeons' decision is still something particular and sometimes defined by his practical routine. The inverted technique is used because it allows cranial flexion, can demonstrate advantages (reduces the need for the use of auxiliary forceps and exposes the ovaries more) and as it is little known, its use is still limited.

\section{CONCLUSION}

The technique of inverted ovariosalpingohisterectomy in cats presented advantages when compared to the traditional technique, as it promoted greater ovarian exposure by allowing uterine cranial flexion, facilitating its manipulation and hemostasis. Although there is no statistical difference in the evaluations performed in this study and in the production of pain stimuli. The total surgical time is similar in both techniques.

The Inverted OSH technique promotes uterine cranial flexion, which may allow, in obese patients, easier manipulation for hemostasis and disinsertion of the ovaries in the feline species when compared to the traditional technique, suggesting the need for further studies in this group of animals.

\section{ACKNOWLEDGMENTS}

The authors would like to thank Professor Cássia Maria Molinaro Coelho for helping to prepare the study and statistical analysis. We would like to thank Editage (www.editage.com) for English language editing. The present work was carried out with support of the Coordination of Improvement of Higher Education Personnel-Brazil (CAPES)-Financing Code 001.

\section{REFERENCES}

ATALLAH, F. A. et al. Complicações pós-cirúrgicas em cadelas submetidas à ovário-histerectomia no Rio de Janeiro. Revista Brasileira de Medicina Veterinária, v. 35, p. 61-69, 2013.

CAMPOS, A. C. S. et al. Ovariosalpingohysterectomy Technique Adapted in Bitches (Canis familiaris): Advantages and Limitations. Acta Scientiae Veterinariae, v. 48, n. 1718, p. 1-6, 2020.

CONCEIÇÃO, M. E. et al. Perspectivas acerca da esterilização cirúrgica em cadelas e gatas. Revista Investigação Medicina Veterinária, v. 15, n. 1, p. 10-15, 2016.
DÁVID, T.; KASPER, I.; KASPER, M. Urogenitaltrakt. In: Atlas der Kleintierchirurgie:Weichteilchirurgie. l.ed. Hannover: Schlütersche, 2000. p. 394-396.

DELCARLO, R. J.; BORGES, A. P. B. Técnicas operatórias no sistema reprodutor. In: OLIVEIRA, $A$. L. A. (Ed.). Técnicas Cirúrgicas em Pequenos Animais. 2. ed. Rio de Janeiro: Elsevier, 2018. p. 238-245.

FERREIRA, G. S. et al. Ovariosalpingohisterectomia em cadela por acesso único - "Single port": Relato de caso. Medvep - Revista Científica de Medicina Veterinária, v. 9, n. 31, p. 672-676, 2011. 
FIGUEIREDO, M. S. Castração Pré-Púbere em Cães e Gatos: Benefícios e Riscos - Revisão de Literatura. 2011. 44 f. Monografia (Residência em Medicina Veterinária) - Universidade Federal de Minas Gerais, Belo Horizonte, 2011.

MACPHAIL, C. M. Cirurgia dos sistemas reprodutivos e genital. In: FOSSUM, T. W. (Ed). Cirurgia de pequenos animais. 4. ed. Rio de Janeiro: Elsevier, 2014. p. 780-826.

MIGLIARI, R.; DE VUONO, R. S. Ovariossalpingohisterectomia em cadelas e gatas-proposta de novos procedimentos.
Revista de Educação Continuada CRMVSP, v. 3, n. 3, p. 28-32, 2000.

MURARO, L.; WHITE, R. S. Complications of ovariohysterectomy procedures performed in 1880 dogs. Tierärztliche Praxis. Ausgabe K, Kleintiere/Heimtiere, v. 42, n. 5, p. 297-302, 2014.

SANTOS, F. C. et al. Complicações da esterilização cirúrgica de fêmeas caninas e felinas. Revisão de literatura. Veterinária e Zootecnia, v. 16, n. 1, p. 8-18, 2009. 